İş ve İnsan Dergisi I The Journal of Human and Work

Y1l | Year: Nisan | April 2020

Cilt-Say1 | Volume-Issue: 7 (1)

ss I pp: $59-76$

doi: $10.18394 /$ iid.612161

e-ISSN 2148-967X

https://dergipark.org.tr/tr/pub/iid

Araştırma Makalesi

\title{
Yüksek Performanslı İnsan Kaynakları Uygulamaları Hizmet Odaklı Örgütsel Vatandaşlık Davranışını Nasıl Etkiler? İş Tutumlarının Aracilık Rolü
}

\author{
How Do High-Performance Human Resources Practices Affect Service-Oriented \\ Organizational Citizenship Behavior? The Mediating Role of Work Attitudes
}

\section{Mert Gürlek $^{\mathrm{a}}$}

MAKALE BİLGISII

Anahtar Kelimeler:

Yüksek Performanslı Insan

Kaynakları Uygulamalart,

Hizmet Odaklı Örgütsel

Vatandaşlık Davranıșı, Ișe

Gömülmüşük, Ișe Adanma,

Otel Endüstrisi

Tarihler:

Geliş 27 Ağustos 2019

Düzeltme geliş 02 Aralık

2019

Kabul 07 Ocak 2020
ÖZ

Bu araştırma yüksek performanslı insan kaynakları uygulamalarının nasıl hizmet odakl örgütsel vatandaşlık davranışını etkilediğini ortaya çıkarmayı amaçlamaktadır. Araştırma modeli yapisal eşitlik modellemesi kullanılarak test edilmiştir. İlişkilerin test edilmesinde kullanılan veri dört ve beş yıldızlı otel işletmelerinin işgörenlerinden $(n=496)$ elde edilmiştir. Bulgular temel olarak yüksek performansl insan kaynaklarl uygulamalarının hizmet odakl örgütsel vatandaşlık davranışı üzerindeki etkisinde işe adanmanın ve işe gömülmüşlüğün tam aracılık rollerine işaret etmektedir. Bu bulguya göre, bir biriyle uyumlu insan kaynakları uygulamaları işe adanmayı ve işe gömülmüşlüğ̈̈ artırmak suretiyle hizmet odaklı örgütsel vatandaşlık davranışını artırmaktadır. Bir başka ifadeyle, işe adanma ve işe gömülmüşlük bağımsız ve bağımlı değişken arasındaki ilişkide kilit bağlantı noktalarını oluşturmaktadır. Sonuç olarak bu araştırma, yüksek performanslı insan kaynakları uygulamalarl ve hizmet odakl örgütsel vatandaşlık davranışı arasındaki ilişki süreçlerine ışık tutarak, alanyazına katkı sağlamaktadır.

\section{A R T I C LE INF O}

\section{Keywords:}

High-Performance Human

Resources Practices,

Service-Oriented

Organizational Citizenship

Behavior, Job

Embeddedness, Work

Engagement, Hotel Industry

Article history:

Received 27 August 2019

Received in revised form 02

December 2019

Accepted 07 January 2020

\begin{abstract}
A B S T R A C T
This research aims to reveal how high-performance human resources practices affect serviceoriented organizational citizenship behavior. Structural equation modeling was used to test the research model. The data used to test the relationships were obtained from employees of four and five-star hotel $(n=496)$. The findings mainly indicate full mediating roles of job embeddedness and work engagement in the effect of high-performance human resources practices on service-oriented organizational citizenship behavior. According to this finding, a set of internally consistent HR practices increase service-oriented organizational citizenship behavior by increasing job embeddedness and work engagement. . In other words, job embeddedness and work engagement are key links in the relationship between independent and dependent variables. As a result, this research contributes to the literature by shedding light on the relationship processes between high-performance human resources practices and serviceoriented organizational citizenship behavior.
\end{abstract}

\footnotetext{
a İletişim kurulacak yazar, Dr. Öğr. Üyesi, Burdur Mehmet Akif Ersoy Üniversitesi, İstiklal Yerleşkesi, Burdur, Turkey. E-mail: mertgurlek89@hotmail.com.ORCID:0000-0002-0024-7746
} 


\section{GİRIŞ}

Konaklama sektörü dünyanın en hızlı gelişen ve en çok gelir sağlayan sektörlerinden biridir (UNWTO, 2018). Bu hızın tetikleyici gücü rakipler tarafından kopyalanması ve taklit edilmesi zor bir kaynak olarak kabul edilen insan kaynaklarıdır. $\mathrm{Bu}$ tür kaynaklar otel işletmeleri için özel öneme sahiptir. Çünkü işletmelerin başarısı çalışanlar ve müşteriler arasındaki etkileşimin başarısına bağlıdır (Domínguez-Falcón, Martín-Santana \& De SaáPérez, 2016). Özellikle sınır birim çalışanlarının tutum ve davranışları müşteri tatminini ve hizmet kalitesini etkilemektedir (Varela González \& García Garazo, 2006; Gürlek, 2018). Konaklama sektöründe, eğer çalışanlar sadece iş tanımlarını takip ederlerse, hizmet kalitesini artırmaları zorlaşmaktadır. $\mathrm{Bu}$ nedenle oteller çalışanlarının hizmet odaklı örgütsel vatandaşlık davranışı (ÖVD) sergilemelerini sağmalıdırlar (Tang \& Tsaur, 2016). Sınır birimi çalışanları tarafından sergilenen bu davranışlar iş tanımlarının ötesinde müşteri hizmetlerine odaklanmakta ve otellerin hizmet sunum kalitesini, rekabet avantajını ve finansal performansını artırmak için gerekli kabul edilmektedir (Tsaur \& Lin, 2004; Nasurdin, Ahmad \& Tan, 2015). Bu nedenle hizmet odaklı ÖVD'nin öncüllerinin belirlenmesi araştırmacılar ve uygulamacılar için değer yaratmaktadır. Şimdiye kadar çok az araştırma konaklama sektöründe hizmet odaklı ÖVD'nin öncüllerini incelemiștir (Varela González \& García Garazo, 2006; Kim, O’Neill \& Cho, 2010; Ma \& Qu, 2011; Tang \& Tang, 2012; Tang \& Tsaur, 2016; Garba, Babalola \& Guo, 2018; Kang \& Jang, 2019; Bavik, 2019; Qiu, Alizadeh, Dooley \& Zhang, 2019).

Oteller sınır birim çalışanları arasında hizmet odaklı davranışlar geliştirmek için yararlı araçlar aramaktadır. Yüksek performanslı insan kaynakları uygulamaları (YPİKU) bu tür davranışları motive edebilir. YPIKU çalışanların yetkinliklerini, motivasyonlarını ve firsatlarını artırmak için dizayn edilmiş birbiriyle uyumlu birbirini tamamlayıcı insan kaynakları (İK) uygulamalardır (Becker \& Huselid, 1998; Mitchell, Obeidat \& Bray, 2013).

Yüksek performanslı İK uygulamaları bazı ödülleri (örneğin: performansa dayalı ödüller) içermektedir. Vatandaşlık davranışlarının resmi rol tanımlarının dışında olmaları ödül ve cezayla motive edilmelerini zorlaştırmaktadır (Organ, 1997). Bu nedenle yüksek performanslı IKK uygulamaları ve örgütsel vatandaşlık davranışı arasındaki ilişkiler aracı değişkenlerle daha iyi açıklanabilir (Kehoe \& Wright, 2013). Podsakoff, MacKenzie, Paine ve Bachrach, (2000) ödülleri kapsayan uygulamaların vatandaşlık davranışlarını iş tutumları aracılığıyla etkileyebileceğini vurgulamıştır. Alfes, Shantz, Truss ve Soane (2013) ise gelecekteki araştırmaları YPİKU ve davranışsal değişkenler arasındaki ilişkide iş tutumlarının aracılık rolünü incelemeye çağırmaktadır. Benzer bir şekilde Karatepe (2016) YPİKU ile hizmet odaklı ÖVD arasındaki ilişkide iş tutumlarının (örneği: işe adanma) aracılık rolünün araştırılması için çağrıda bulunmuştur. Konaklama sektöründe, her ne kadar iş tatmini (Varela González \& García Garazo, 2006; Kang, Kim, Choi \& Li, 2020), işe adanma (Choo, 2016; Kim \& Gatling, 2019) gibi iş tutumlarının hizmet odaklı ÖVD'leri artırdığ 1 tespit edilse de, hiçbir araştırma iş tutumlarının YPİKU ile hizmet odaklı ÖVD arasındaki ilişkide aracılık rolünü incelememiştir. $\mathrm{Bu}$ iddiayı haklı çıkarmak için YPİKU ve hizmet odaklı ÖVD arasındaki ilişkileri aracı değişkenlerin açısından inceleyen az sayıdaki araştırmayı belirtmekte yarar bulunmaktadır. Tang ve Tang (2012) konaklama sektöründe YPIKU'nın örgütsel iklim aracılığıyla hizmet odaklı ÖVD'yi artırdığına dair ampirik kanıtlar sunmuşlardır. Lin ve Liu (2016) YPİKU'nun hizmet iklimi aracılığıla hizmet odaklı ÖVD'yi artırdığını tespit etmiştir. Liu ve Lin (2019) YPİKU'nun beceri esnekliği aracılığıyla hizmet odaklı ÖVD'yi artırdığını tespit etmiştir. Nadeem, Riaz ve Danish (2019) söz konusu iki değişken arasında işgören dayanaklılığının aracılık rolünü tespit etmişlerdir. Görüldüğü üzere, YPİKU ile hizmet odaklı ÖVD arasındaki ilişkide iş tutumlarının aracılık rolü incelenmemiştir. $\mathrm{Bu}$ araştırma yukarıdaki bilgi boşluğunu doldurmak amacıyla konaklama sektörü için önemli ve gerekli bir dizi iş tutumunun aracılık rolünü incelemeyi amaçlamaktadır.

Sınır birim çalışanlarının iş yönelik tutumları oteller için hayati önem taşımaktadır. İşe ilişkin tutumlar hizmet kalitesini olumlu ya da olumsuz yönde etkileyebilmektedir (Kusluvan, Kusluvan, Ilhan \& Buyruk, 2010; Gürlek \& Tuna, 2019). İşe adanma ve işe gömülmüşlük müşteri memnuniyetinin ve hizmet kalitesinin temel koşulu olarak kabul edilmektedir (Karatepe, 2012; Karatepe \& Vatankhah, 2014). Diğer sektörler ile kıyaslandığında, işe adanma konaklama sektörü için daha önemlidir (Lee \& Ok, 2016; Gürlek, 2018). Adanmış kişiler, yüksek bir enerji duygusuna ve iş aktiviteleri ile güçlü bir bağa sahiptirler (Schaufeli, Salanova, González-Romá \& Bakker, 2002). İşe adanma çalışanların resmi rol gereksinimlerinin ötesine geçmelerini teşvik eden önemli bir unsur olarak kabul edilebilir. Çünkü adanmış çalışanlar müşteri ihtiyaçlarının karşılanmasına yönelik çaba sarf etmek için daha isteklidirler (Karatepe, 2013a; Gürlek, 2018). Diğer taraftan işe daha fazla gömülü çalışanların daha az gömülü olanlara göre daha fazla ÖVD sergileyecekleri ön görülmektedir (Karatepe \& Vatankhah, 2014). Sosyal değişim 
teorisine göre eğer örgütler çalışanlarına ekonomik ve sosyo-duygusal değişim kaynakları sunarlar ise çalışanlar örgüte olumlu tepkiler vereceklerdir (Blau, 1964; Saks, 2006). Buna göre işletmeler YPIKU ile çalışanların yetkinliklerini, motivasyonlarını ve firsatlarını artırırlarsa, çalışanlar daha derin işe gömülmüşlük ve adanma ile örgüte karşılık vereceklerdir. $\mathrm{Bu}$ olumlu iş tutumları da hizmet odaklı ÖVD’yi artıracaktır. Bu araştırma YPİKU'yu iş tutumlarının bir öncülü, hizmet odaklı ÖVD'yi ise iş tutumlarını bir sonucu olarak görmektedir.

\section{TEORIK ÇERÇEVE VE HIPOTEZLER}

\subsection{Yüksek performanslı insan kaynakları uygulamaları}

Yüksek performanslı insan kaynakları uygulamaları (YPIKU) firma performansını daha yüksek bir seviyeye taşıyan örgütsel uygulamalar olarak kabul edilmektedir (Murphy \& Williams, 2010). Alanyazında yoğun bir şekilde ele alınmasına rağmen, araştırmacıların üzerinde uzlaştığı ortak bir YPIKKU tanımı bulunmamaktadır (Boxall \& Macky, 2009). Fakat tüm tanımlar çalışanların yetenek, bilgi ve motivasyonlarını artırarak onları rekabetçi üstünlük kaynağı haline getiren uygulamaları vurgulayan ortak bir temaya sahiptir (Guthrie, 2001). Bu uygulamaların alanyazında değişik şekillerde ifade edildiği görülmektedir: yüksek performanslı iş sistemleri (Becker \& Huselid, 1998; Jeon \& Shin, 2019), yüksek bağlılık iş sistemleri (Xiao \& Björkman, 2006; Chiang, Shih \& Hsu, 2014)) en iyi uygulamalar (Theriou \& Chatzoglou, 2009), insan kaynakları yönetimi sistemleri (Delaney ve Huselid, 1996) ve yüksek katılım iş süreçleri (Macky \& Boxall, 2008). Bu kavramlar birbirilerinde küçük farklılıklara sahip olsalar da aynı teorik anlayışın ürünleridir (Gürlek, 2019a).

YPİKU'nın hangi uygulamalar içereceği konusunda da bir fikir birliği bulunmamaktadır. Delaney ve Huselid'in (1996:967) ifadesiyle "hiçbir iki araştırma İKY uygulamalarını aynı yolla ölçmemiştir". Araştırmalar yüksek performans insan kaynakları uygulamalarını ölçmek için ya kaynak tabanlı ya da kontrol tabanlı görüşü benimsemişlerdir (Bamberger \& Meshoulam, 2000). Kaynak tabanlı görüş eğitim ve geniş kariyer seçenekleri gibi çalışanların içsel gelişimine odaklanırken, kontrol tabanlı görüş çalışanların performansının izlenmesi ve yönetilmesine odaklanmaktadır (Zhang, Wan \& Jia, 2008). Bamberger ve Meshoulam (2000) bu yaklaşımların hiç birinin yüksek performanslı insan kaynakları uygulamalarını ölçmek için yeterli olmadığını belirtmiş ve bu iki yaklaşımın entegre edildiği bir taslak sunmuştur. Taslağa göre bu iki yaklaşım üç ana insan kaynakları alt sistemini yansıtmaktadır: 1) seçici işe alma, eğitim ve iş güvenliği garantisini içeren insan akışı, 2) performans değerlendirme ve ödülleri içeren değerlendirme ve ödüller, 3) güçlendirme ve çalışanların kararlara katılımını içeren istihdam ilişkileri. Bu araştırma Bamberger ve Meshoulam'un (2000) taslağını benimsemekte ve yüksek performanslı insan kaynakları uygulamalarını örgütsel performansı kolektif bir şekilde etkileyen birbiriyle uyumlu uygulamaların kombinasyonu olarak tanımlamaktadır (Sun, Aryee \& Law, 2007). Sistem teorisi perspektifinden, yüksek performanslı insan kaynakları uygulamaları, birbiriyle uyumlu uygulamaların bir arada eş zamanlı uygulanmasının, tek bir uygulamadan daha fazla performansı artıracağ 1 iddiasına dayanmaktadır (Gürlek, 2019a).

\subsection{Hizmet odaklı örgütsel vatandaşlık davranışı}

Örgütsel vatandaşlık davranışı (ÖVD) “doğrudan veya açıkça resmi ödül sistemi tarafından tanımlanmayan ve bir örgütün etkili ve verimli işleyişini teşvik eden bireysel davranış" olarak tanımlanmaktadır (Organ, Podsakoff \& MacKenzie, 2006: 10). Araştırmalar genel olarak farklı tip örgütler için aynı ÖVD’lere odaklanmışlardır. Fakat sektörel farklilıklar nedeniyle, ÖVD'ler farklılaşabilmektedir. Borman ve Motowidlo (1993) bazı ÖVD'lerin belirli örgüt tipleri için diğerlerinden daha uygun olduğu vurgulamıştır. Örneğin hizmet işletmelerinde çalışanlar müşterilerle yakın temas halinde bulunmaktadır. $\mathrm{Bu}$ durum bazı özel ÖVD'leri gerektirmektedir. Bu nedenle araştırmacılar hizmet sektöründe ÖVD'nin müşteri ve hizmet odaklı vatandaşlık davranışlarını içerecek şekilde ele alınması gerektiğini ifade etmişlerdir (Van Dyne, Graham \& Dienesch, 1994; Sun vd., 2007; Yung, Chou \& Lopez-Rodriguez, 2013).

Hizmet odaklı ÖVD, hizmet çalışanlarının müșterilere yönelik, resmi rol gereksinimlerinin ötesinde gönüllü olarak gerçekleştirdikleri davranışlar olarak tanımlanmaktadır (Bettencourt \& Brown, 1997). Bettencourt, Gwinner ve Meuter (2001) sadakat, katılım ve hizmet sunumu unsurlarından oluşan üç boyutlu hizmet odaklı ÖVD tipolojisi geliştirmişlerdir. Sadakat, çalışanın dışarıya karşı örgütsel imajı ve sunulan malhizmetleri desteklemesini; katılım hizmet kalitesini artırmak için çalışanın örgüt ve iş arkadaşları ile gönüllü iletişimini; hizmet sunumu çalışanın hizmet sunum sürecinde vicdanlı (conscientious) bir şekilde davranmasını ifade etmektedir (Bettencourt vd., 2001). Daha detaylı bir anlatımla, sadakat boyutu, çalışanların örgüt dışında bir avukat gibi hareket ederek sadece örgütün imajını değil aynı 
zamanda örgütün sunduğu mal ve hizmetleri savunmasını; katılım boyutu çalışanların örgütün ve çalışma arkadaşlarının hizmet sunumunu iyileştirmek için inisiyatif almasını; hizmet sunumu boyutu hizmet sunumunda çalışanların müşterilere yönelik vicdanlı, güvenilir, duyarlı ve saygılı davranmasını içermektedir (Sun vd., 2007).

\section{3. İşe Gömülmüşlük}

"İşe gömülmüşlük, iş görenlerin işyerinde kalmasını etkileyen faktörler grubunu ifade etmektedir" (Mitchell vd., 2001: 1104). Bağlantı, uyma ve fedakârlık işe gömülmüşlüğün üç kritik unsurudur. Bağlantı, işgören ile örgüt ya da çalışma arkadaşları arasındaki resmi veya resmi olmayan iletişimleri ifade etmektedir. İşgörenin yaşadığı çevreyi, işyeri arkadaşlarını ve diğer arkadaşlarını içeren sosyal psikolojik bir iletişim ağı bulunmaktadır. Kişi ve ağ arasındaki bağlantının yüksek olması işe ve örgüte olan bağlılı̆̆1 artırmaktadır. Uyum, işgörenin kişisel değerleri, kariyer hedefleri, geleceğe dair planları ve becerileri ile örgüt arasındaki uyumu ifade etmektedir. Fedakârlık, işgörenin işten ayrılması durumunda, kaybedeceği bir takım maddi ve psikolojik yararları ifade etmektedir (Mitchell vd., 2001; Gürlek, 2019b). İşe gömülü çalışanlar işleriyle uyumlu olmaktadırlar, çalışma arkadaşlarıyla resmi yada resmi olmayan iletişime sahiptirler ve örgüt içindeki değerli şeylerden fedakarlık etmek istemezler (Karatepe, 2013b). İşe gömülmüşlük örgütler için oldukça yaralıdır. Çünkü işe gömülü iş görenler işlerini en iyi şekilde yapmak için daha fazla çalışırlar, daha az devamsızlık eğilimi gösterirler ve işten kalmaya devam ederler (Kanten, Kanten \& Gürlek, 2015; Gürlek, 2018; Gürlek, 2019b)

\section{4. İşe Adanma}

Schaufeli vd. (2002: 74) işe adanmayı, "dinçlik, bağlanma ve yoğunlaşma tarafından tanımlanan iş ile ilgili olumlu ve tatmin edici ruhsal durum olarak tanımlamıştır". Schaufeli vd. (2002) teorik taslağında, dinçlik bireyin çalışırken sahip olduğunu yüksek düzeyde enerjiyi ve zihinsel esnekliği; işine için çaba sarf etme isteğini ve zorluklar karşısında sabır gösterme eğilimini ifade etmektedir. Bağlanma, bireyin işini yönelik heyecan, coşku, ilham, gurur ve mücadele azmi duygularını ifade etmektedir. Yoğunlaşma, kişinin işine tamamen konsantre olmasını, kendini işten ayıramamasını, işte zamanın nasıl geçtiğini anlamamasını ve tamamen işine odaklanması anlamına gelmektedir (Schaufeli vd., 2002: 74-75; Gürlek, 2018: 56-57).

\subsection{Yüksek performanslı insan kaynakları uygulamaları ve işe adanma}

Araştırmalar işe adanma ve iş çıktıları arasındaki ilişkileri yoğun bir şekilde incelemesine rağmen (Xanthopoulou vd., 2007; Demerouti \& Bakker, 2011), işe adanmayı etkileyen örgütsel ve bireysel öncüller henüz tam olarak bilinmemektedir. Özellikle işe adanmanın yüksek performanslı İK uygulamaları gibi örgütsel düzeydeki öncüllerini inceleyen daha az teorik ve ampirik çalışma mevcuttur (Karatepe, 2013a; Zhong, Wayne \& Liden, 2016). Bu bakımdan yüksek performanslı insan kaynakları uygulamaları ve işe adanma arasındaki ilişkileri incelemek önemlidir.

Saks (2006) işe adanma ve öncülleri arasındaki ilişkiyi sosyal değişim teorisi ile açıklamıştır. $\mathrm{Bu}$ teori çalışanların işlerine niçin daha çok veya daha az adandıklarını açıklamak için bir teorik temel sunmaktadır (Saks, 2006; Gürlek, 2018). Eğer örgütler çalışanlarına ekonomik ve sosyo-duygusal değişim kaynakları sunarlar ise çalışanları örgüte daha derin bir adanma ile karşılık vereceklerdir (Lee, Choi, Moon \& Babin, 2014; Gürlek, 2018). Seçici işe alma, geniş beceri eğitimi, geniş kariyer yolları, garantili iş güvenliği ve geniş açık uçlu ödüller gibi yüksek performanslı İK uygulamaları (Sun vd., 2007), örgütün çalışanlarına yatırım yaptığını göstermektedir (Salanova \& Schaufeli, 2008; Shaw, Dineen, Fang \& Vellella, 2009). Sosyal değişim teorisine göre, İK uygulamalarıyla çalışanlara yapılan yatırımlar onları örgüte daha yüksek bir adanmayla karşılık vermeye itecektir (Zhong vd., 2016). Araştırmalar işe adanma süreçlerini açıklamak için iş kaynakları ve talepleri (JD-R model) modelini kullanmışlardır (Schaufel \& Bakker, 2004; Xanthopoulous vd., 2007; Sweetman \& Luthans, 2010; Gürlek, 2018). İş talepleri, "sürekli fiziksel ve / veya zihinsel çaba gerektiren ve dolayısıyla belirli fizyolojik ve psikolojik maliyetlerle ilişkili olan işin fiziksel, sosyal veya örgütsel yönlerini” ifade etmektedir. Diğer yandan, "iş kaynakları, iş hedeflerine ulaşmada, iş taleplerini azaltmada veya kişisel gelişim, öğrenme ve gelişmeyi teşvik etmede kullanışlı kabul edilen işin fiziksel, sosyal veya örgütsel yönlerini” ifade etmektedir (Llorens, Bakker, Schaufeli \& Salanova, 2006: 379). Yüksek performanslı İK uygulamaları bir iş kaynağı olarak düşünülebilir ve işe adanmayı olumlu yönde etkilemesi muhtemeldir (Cooke, Cooper, Bartram, Wang \& Mei, 2019). Alanyazında sınırlı sayıda araştırma yüksek performanslı İK uygulamalarının işe adanmayı artırdığını tespit etmiştir. Örneğin, Huang, Ma ve Meng (2018) Çin'de imalat ve hizmet sektörlerinde gerçekleştirdiği araştırmada Yüksek performanslı İK uygulamalarının işe adanmayı artırdığı tespit etmiştir. Mihail ve Kloutsiniotis (2016) Yunanistan'da hastane çalışanları üzerinde gerçekleştirdikleri araştırmada yükssek performanslı İK uygulamalarının işe adanmanın önemli bir 
öncülü olduğunu tespit etmişlerdir. Benzer bir bulguya Karadas ve Karatepe (2019) Romanya otel endüstrisinde gerçekleştirdikleri araştırmada ulaşmışlardır. Yukarıdaki bilgilere dayanarak aşağıdaki hipotez ileri sürülmüştür.

$\mathbf{H}_{1}$ : Yüksek performanslı insan kaynakları uygulamaları işe adanmayı olumlu olarak etkilemektedir.

\subsection{Yüksek performanslı insan kaynakları uygulamaları ve işe gömülmüşlük}

Yüksek performanslı İK uygulamaları işe gömülmüşlüğün üç unsuruyla ilişkilidir. $\mathrm{Bu}$ tür uygulamalar işgörenin yöneticiler ve çalışma arkadaşlarıyla daha iyi bağlantı kurmasına yardımcı olur, bireyin değerleriyle örgütün değerleri arasında uyumu sağlar ve sonuç olarak çalışanların bu tür faydalardan vazgeçmelerini engeller (Karatepe \& Vatankhah, 2014). Örgütler işe alma esnasında örgütle genel bir uyuma sahip çalışanları seçerek işe gömülmüşlüğün uyum unsurunun gelişmesini kolaylaştırır (Bergiel, Nguyen, Clenney \& Stephen Taylor, 2009) Daha uyumlu çalışanlar işe alındığı zaman, iş görenin kişisel değerleri, kariyer hedefleri ve geleceğe dair planları ile örgüt arasındaki uyum artabilir. Ayrıca örgüt eğitim uygulamalarıyla örgüte uyumla ilgili bilgileri çalışanlara iletebilir (Ghosh \& Gurunathan, 2015). Böylece İK uygulamaları çalışanları daha çok işe gömülü hale getirebilir.

İK uygulamaları çalışanın örgütteki bağlantılarını etkilemektedir. Örgütsel değerleri paylaşan bireyler diğerleriyle daha iyi iletișim ve güçlü bağlar kuracaklardır (Cable \& DeRue, 2002). Ayrıca İK uygulamaları takım çalışmasını teşvik eder ve böylece çalışanın örgütteki bağlantıları artar. İşe gömülmüşlügün fedakârlık boyutu açısından, örgütler çalışanları elde tutmak, motive etmek ve çekmek için ücret ve ödüllendirme gibi kaynakları kullanırlar. $\mathrm{Bu}$ uygulamalar yoluyla örgütler çalışanlarına örgütten ayrılırlarsa nelerden fedakarlık edeceklerini belirten sinyaller gönderirler (Wheeler, 2010). Bu sinyalleri alan çalışanlara işlerine daha fazla gömülebilirler.

Sosyal değişim teorisi göre (Blau, 1964), işgörenler bilgi ve becerilerinin geliştirilmesi için eğitildiklerini, inisiyatif almak için güçlendirildiklerini ve performanslarına göre ödüllendirildiklerini görürlerse örgüte daha yüksek bir gömülmeyle karşılık vereceklerdir (Karatepe, 2013b). Bu bilgilere ek olarak alanyazında birkaç araştırma yüksek performanslı İK uygulamalarının işe gömülmüşlüğü artırdığını tespit etmiştir (Bergiel vd., 2009; Karatepe \& Karadas, 2012; Tian, Cordery ve Gamble, 2016; Afsar, Shahjehan \&
Shah, 2018). Örneğin, Afsar vd. (2018) Tayland otel endüstrisinde gerçekleştirdikleri araştırmada yüksek performanslı İK uygulamalarının işe gömülmüşlüğü olumlu ve anlamlı olarak etkilediğini tespit etmişlerdir. Yukarıdaki bilgilere dayanarak aşağıdaki hipotez ileri sürülmüştür.

$\mathbf{H}_{2}$ : Yüksek performanslı insan kaynakları uygulamaları işe gömülmüşlüğü olumlu olarak etkilemektedir.

\section{7. İş tutumları ve hizmet odaklı örgütsel vatandaşlık davranışı}

İşe gömülmüşlük motivasyonel niteliği nedeniyle çalışanların rol içi ve rol dışı performanslarını etkileyebilir ( $\mathrm{Ng} \&$ Feldman, 2009). Yüksek düzeyde işe gömülü işgörenlerin çalışma arkadaşları ve örgütle bağlantıları yüksektir, kişi ve örgüt arasındaki uyum mükemmeldir ve çalışan örgüt tarafından sunulan değerli şeylerden vazgeçip işten ayrılmak istemez. Bu nedenle büyük bir olasılıkla işine daha çok gömülü çalışanlar, daha fazla vatandaşlık davranışı göstereceklerdir (Lee, Mitchell, Sablynski, Burton \& Holtom, 2004). Özellikle çalışanların birbirileriyle bağlantılı olmaları ve aynı sosyal ağın parçası olmaları birbirlerine yardım etmelerine neden olacaktır. Çalışanın işi, çalışma arkadaşları ve örgütleriyle uyumlu olması ve kolayca vazgeçemeyeceği yararlara sahip olması doğal olarak daha fazla hizmet odaklı örgütsel vatandaşlık davranışı sergilemesine neden olacaktır. Alanyazında birkaç araştırma işe gömülmüşlüğün hizmet odaklı örgütsel vatandaşlık davranışını olumlu yönde etkilediğini tespit etmiștir (Lee vd. 2004; Sekiguchi vd., 2008; Holtom vd., 2012; Luu, 2019). Örneğin, Luu (2019) Vietnam'da kamu çalışanları üzerinde gerçekleştirdikleri araştırmada işe gömülmüşlüğün hizmet odaklı örgütsel vatandaşlık davranışını olumlu ve anlamlı olarak etkilediğini ortaya çıkarmışlardır.

$\mathbf{H}_{3}$ : İş gömülmüşlük hizmet odaklı örgütsel vatandaşlık davranışını olumlu olarak etkilemektedir.

Tükenmişlik antitez yaklaşımı bağlamında, işe adanma tükenmişliğin tersi olarak kabul edilmektedir (Gürlek, 2018). Araştırmalar tükenmişliğin rol ötesi davranışları olumsuz etkilediğini göstermektedir (Chiu \& Tsai 2006; Babcock-Roberson \& Strickland, 2010). Bu nedenle işe adanmanın ÖVD'yi olumlu yönde etkilemesi beklenebilir. Daha spesifik olarak ifade etmek gerekirse, işine daha çok bağlanan ve yoğunlaşan aynı zamanda kendisini işte dinç hisseden çalışanların daha yüksek düzeyde hizmet odaklı örgütsel vatandaşlık davranışı sergilemesi 
beklenebilir. Alanyazında birkaç araştırma işe adanmanın diğer rol ötesi davranışları olumlu yönde etkilediğini tespit etmiştir (Matta, Scott, Koopman \& Conlon, 2015; Gupta \& Sharma, 2018; Kim \& Gatling, 2019). Örneğin, Kim ve Gatling (2019) ABD otel endüstrisinde gerçekleştirdikleri araştırmada işe adanmanın hizmet odaklı örgütsel vatandaşlık davranışını olumlu ve anlamlı olarak etkilediğini ortaya çıkarmışlardır.

$\mathbf{H}_{4:}$ İş adanma hizmet odaklı örgütsel vatandaşlık davranışı olumlu olarak etkilemektedir

\section{8. İş tutumlarının aracılık rolü}

Yüksek performanslı İK uygulamalarıyla hizmet odaklı örgütsel vatandaşlık davranışı arasındaki ilişki mekanizmasının aydınlatılmasına yönelik çok sayıda araştırma çağrısı bulunmaktadır (örn: Alfes, Shantz, Truss \& Soane, 2013; Karatepe, 2016). Bu çağrılarla tutarlı olarak birkaç araştırma söz konusu ilişki mekanizmasının aydınlatmaya çalışmışlardır. Örneğin, yüksek performanslı İK uygulamalarıyla hizmet odaklı örgütsel vatandaşlık davranışı arasındaki ilişkide örgütsel iklim (Tang \& Tang, 2012), hizmet iklimi (Lin \& Liu, 2016), beceri esnekliği (Liu \& Lin, 2019), işgören dayanıklılı̆̆ (Nadeem, Riaz \& Danish, 2019) aracı değişkenler olarak ele alınmıştır. Alanyazında, yarar ve firsat sağlayıcı uygulamaların vatandaşlık davranışlarını iş tutumları aracılığıyla etkileyebileceği vurgulanmasına rağmen (Podsakoff vd., 2000), iş tutumlarının (işe adanma ve işe gömülmüşlük) aracılık rolü ihmal edilmiştir. $\mathrm{Bu}$ araştırmada, yüksek performanslı İK uygulamalarının hizmet odaklı örgütsel vatandaşlık davranışını işe adanma ve işe gömülmüşlük aracılığıyla etkileyeceği iddia edilmektedir. İlgili iddia, aşağıda yer alan teorik arka plana dayandırılmaktadır.

Yüksek performanslı insan kaynakları uygulamaları örgüt ve işgören arasındaki ilişkileri yönetmek için önemli bir örgütsel teşvik aracıdır (Zhang vd., 2008). Bu uygulamalar örgütün çalışanları ile uzun dönemli bir değişim ilişkisi kurma niyetinde olduğuna işaret etmektedir (Sun vd., 2007). Eğer bir örgüt çalışanlarını kolayca işten çıkarılabilir kısa vadeli kaynaklar olarak görüyorsa, bu sosyal değişim ilişkisinden ziyade bir ekonomik ilişkiyi işaret etmektedir (Paré \& Tremblay, 2007). Bunun zıddı olarak, yüksek performanslı insan kaynakları uygulamaları örgütün çalışanların mutluluğunu umursadığını, onlara güvendiğini, onlara yatırım yaptığını, onların refah ve gelişimiyle ilgilendiğini gösterir (Snape \& Redman, 2010).

Sosyal değişim teorisine göre (Blau, 1964), destekleyici iş çevresi algılayan işgörenler kendilerini örgüt yararına olumlu davranış sergileme konusunda yükümlü hissederler. Eğer bir otel yüksek performanslı İK uygulamalarını etkin bir şekilde uygularsa, çalışanlar kendileriyle örgütleri arasında olumlu bir değişim ilişkisi algılayacaklar (Kehoe \& Wright, 2013), ve kendilerine yönelik gerçekleştirilen İK uygulamalarına gönüllü davranışlar sergileyerek karşılık vereceklerdir. Bununla beraber işgörenlerin İK uygulamalarına nasıl karşılık verecekleri üzerinde durulması gereken bir konudur. Vatandaşlık davranışlarının resmi rol tanımlarının dışında olmaları nedeniyle ödül, firsat ve yararları içeren İK uygulamaları ile doğrudan teşvik edilmeleri zordur (Organ, 1997). Çünkü rol içi davranışlar yarar sağlayıcı araçlarla teşvik edilebilirken, gönüllü davranışları için bu oldukça zordur (Organ, 1990). Bu nedenle, önceki araştırmalar yüksek performanslı İK uygulamalarıyla vatandaşlık davranışı arasında ilişkileri doğrudan değil, bazı aracı değişkenler kullanarak açıklamışlardır (Sun vd., 2007; Kehoe \& Wright, 2013). İK uygulamalarının bazı ödülleri ve firsatları kapsaması nedeniyle doğrudan vatandaşlık davranışlarını açıklaması zordur. $\mathrm{Bu}$ nedenle iki değişken arasındaki ilişkiye bazı değişkenler aracılık ediyor olabilir. Podsakoff vd. (2000) yarar ve firsat sağlayıcı uygulamaların vatandaşlık davranışlarını doğrudan değil, iş tutumları aracılığıyla etkileyebileceğini vurgulamışlardır. $\mathrm{Bu}$ bilgiler ışı̆̆ında iş tutumlarının yüksek performanslı İK uygulamalarının hizmet odaklı örgütsel vatandaşlık davranışı üzerindeki etkisinde tam aracılık rolü oynayacağı ileri sürülebilir. $\mathrm{Bu}$ ilişki mekanizmasına göre, yüksek performanslı İK uygulamaları ile yönetildiklerini algılayan çalışanlar sosyal değişim teorisinin karşılıklılık ilkesine dayalı olarak (Blau, 1964), büyük bir olasılıkla yüksek düzey işe adanma ve işe gömülmeyle örgüte karşılık vereceklerdir. Artan olumlu iş tutumları ise çalışanların yüksek düzeyde hizmet odaklı örgütsel vatandaşlık davranışı sergilemelerine neden olacaktır.

Yukarıdaki bilgilere dayanarak aşağıdaki hipotez ileri sürülmüştür.

$\mathbf{H}_{5:}$ İşe adanma ve işe gömülmüşlük yüksek performanslı insan kaynakları uygulamalarının hizmet odaklı örgütsel vatandaşlık davranışı üzerindeki etkisine aracılık eder.

\section{YÖNTEM}

\section{1. Örneklem}

Araştırmanın evrenini Ankara'daki dört ve beş yıldızlı otel işletmelerinin işgörenleri 
oluşturmaktadır. Ankara ilinde 26 adet beş yıldızlı 55 adet dört yıldızlı otel işletmesi bulunmaktadır (Kültür ve Turizm Bakanlığı, 2019). Kolayda örnekleme yöntemi kullanılarak 10'u beş yıldızlı, 17'si dört y1ldızlı olmak üzere toplam 27 adet otel işletmesi araştırmaya dahil edilmiştir. Otellerin her birine 30 adet anket formu teslim edilmiş ve yöneticilerden anketleri rastlantisal olarak işgörenlere dağıtmaları talep edilmişti. Bir ay sonra anketler otel işletmelerinde araştırmacı tarafından toplanmış ve 522 adet anket elde edilmiştir. Elde edilen anketler incelemiş ve kullanılabilir olmaya 26 anket veri setinden çıkarılmıştır. Sonuç olarak 496 adet kullanabilir anket elde edilmiştir. Anketlerin geri dönüş oranı yaklaşık olarak \% 61 'dir.

Araştırmaya katılanların \%51'erkeklerden (253) \%49'u (243) kadınlardan oluşmaktadır. Eğitim durumu açısından, katılımcıların yaklaşık olarak \% 41'i (203) lisan ve ön lisans, \% 45'si (223) lise, 14'ü (69) ilköğretim düzeyinde eğitim almıştır. Katılımcıların yaklaşık olarak \%87'si (432) işgören pozisyonunda, \% 13'ü (64) alt ve orta düzey yönetici pozisyonunda çalışmaktadır.

\subsection{Veri Analizi}

Ölçüm modelinin ve yapısal modelin testi için yapısal eşitlik programından (AMOS) yararlanılmıştır. Araştırma modelini test etmek için Anderson ve Gerbing'in (1988) iki aşamalı yaklaşımı takip edilmiştir. Bu yaklaşıma göre ölçüm modeli kabul edilebilir uyum indislerine sahipse, yapısal model test edilmektedir. Yüksek performanslı İK uygulamaları, işe adanma ve hizmet odaklı örgütsel vatandaşlık davranışı yapılarının çok boyutlu doğaları nedeniyle ikinci düzey değişkenler olarak analizi dahil edilmişlerdir.
Yapısal eşitlik programı en çok olabilirlik yöntemini kullanmaktadır. Bu yöntem için normal dağılım varsayımının sağlanması gerekmektedir. Çarpıklık (-0.241) ve basıklık (-0. 821) değerlerinin normal dağılım varsayımını sağladığı görülmektedir (Kline, 2011).

Aracılık analizi için gerekli olan şartlar Baron ve Kenny (1986) tarafından sağlanan ilkeler kullanılarak değerlendirilmiştir. Tam ve kısmi aracılık modelleri $\chi 2$ farklılık testi kullanılarak karşılaştırılmıştır (James, Mulaik \& Brett, 2006). Spesifik olarak, kısmi aracılık modeli yüksek performanslı İK uygulamalarının hizmet odaklı örgütsel vatandaşlık davranışı üzerindeki doğrudan etkilerinin yanı sıra yüksek performanslı İK uygulamalarının ișe adanma ve ișe gömülmüşlük yoluyla hizmet odaklı örgütsel vatandaşlık davranışı üzerindeki dolaylı etkilerinden oluşmuştur. Tam aracılık modeli ise yüksek performanslı İK uygulamalarının işe adanma ve işe gömülmüşlük yoluyla hizmet odaklı örgütsel vatandaşlık davranışı üzerindeki dolaylı etkilerini içermiştir (Şekil 1)

\section{3. Ölçüm Değișkenleri}

$\mathrm{Bu}$ araştırmada bir (kesinlikle katılmıyorum) ve beş (kesinlikle katılıyorum) arasında değişen beşli likert tipi ölçek kullanılmıştır. Ölçekler İngilizce alanyazınından alınmıştır. $\mathrm{Bu}$ nedenle, dilsel geçerlik çalışması yapılmıştır. Brislin (1970) tarafindan ileri sürülen aşamalar takip edilerek, kullanılan ölçekler hem Türkçe hem de İngilizce bilen üç dil uzmanı tarafindan ters çeviri yöntemi kullanılarak Türkçeye çevrilmiştir. Araştırmada kullanılan ölçeklere ilişkin bilgiler aşağıda sunulmuştur.

Yüksek performanslı insan kaynakları

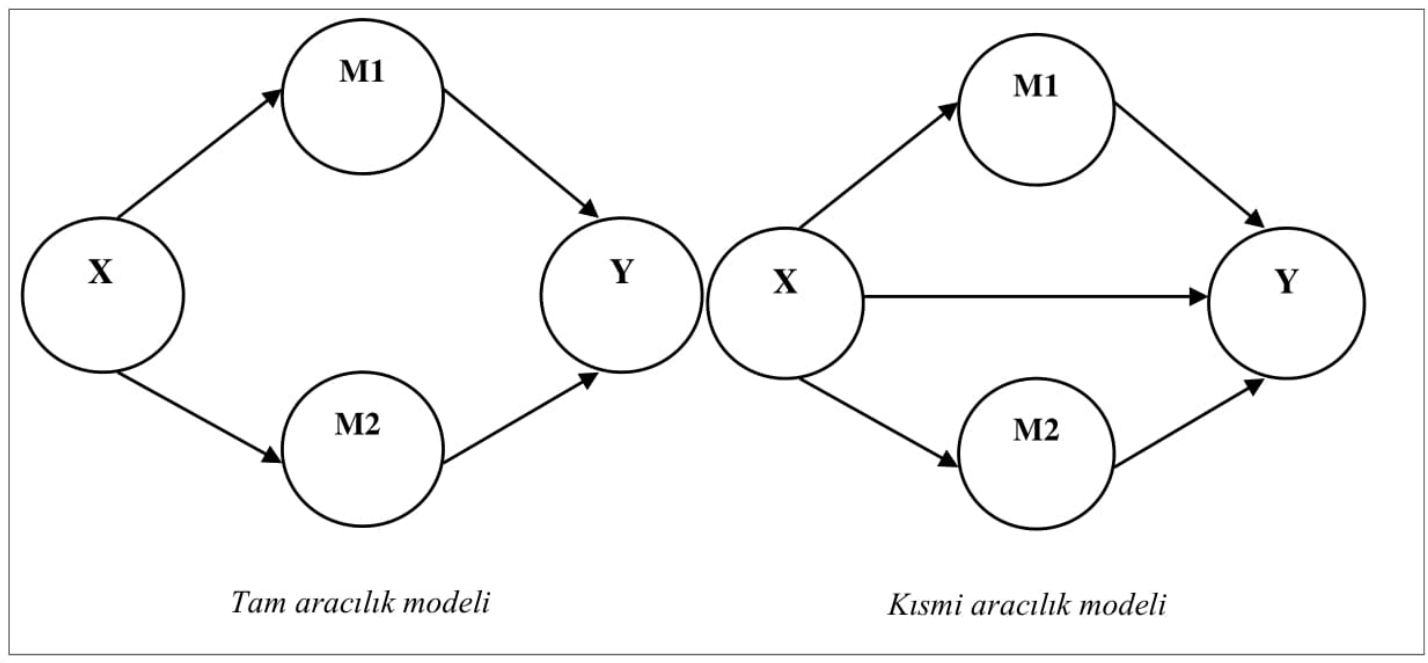

Şekil 1: Tam ve kısmi aracılık modelleri (James vd., 2006; Sardeshmukh \& Vandenberg, 2017) 
uygulamaları, seçici işe alma, kapsamlı eğitim, istihdam güvenliği, performans değerlendirme, ödüllendirme ve güçlendirme olmak üzere altı uygulamadan oluşmaktadır. İK uygulamalarının tümünü birlikte ölçen bir ölçek olmadığından (Gürlek, 2019a) her bir uygulamaya ait ifadeler önceki araştırmalardan alınmıştır. Seçici işe alma ve kapsamlı eğitim değişkenleri ölçmek için Sun vd. (2007) çalışmasından alınan dörder ifade kullanılmıştır. İstihdam güvenliği Delery and Doty'nin (1996) çalışmasından alınan dört ifadeyle ölçülmüştür. Performans değerlendirme Tang ve Tang (2012) çalışmasından elde edilen üç ifadeyle ölçülmüştür. Ödüller ve güçlendirme Boshoff ve Allen (2000) çalışmasından alınan dokuz ifadeyle ölçülmüştür. Ödüller beş ifade içerirken, güçlendirme dört ifade içermektedir. İşe adanmayı ölçmek için Utrecht İş adanma Ölçeğinin (dokuz ifade) kısa versiyonu kullanılmıştır (Schaufeli ve ark. 2006). Her bir boyut üç ifadeden oluşmaktadır. İşe gömülmüşlük Crossley ve arkadaşları (2007) tarafindan geliştirilen genel /küresel işe gömülmüşlük ölçeği kullanılarak ölçülmüştür. Ölçek yedi ifadeden oluşmaktadır. Hizmet odaklı ÖVD Bettencourt vd. (2001) çalışmasından adapte edilen 16 ifade kullanılarak ölçülmüştür.

\section{4. Ölçüm modeli sonuçları}

Ölçüm modeli sonuçları Tablo 1'de gösterilmiştir. Sonuçlara göre ölçüm modeli veriyle uyumludur $(\chi 2=2997.026 \mathrm{df}=1459, \mathrm{p}<0.001 \chi 2 / \mathrm{df}=2.054$, RMSEA $=0.065$, CFI $=0.96$, NFI $=0.94$ ). Uyum indisleri kabul edilebilir sınırları içerisindedir (Schermelleh-Engel, Moosbrugger \& Müller, 2003). Faktör yükleri 0.50'nin aşağısında kalması nedeniyle hizmet odaklı örgütsel vatandaşlık davranışı ölçeğinden iki ifade çıkarılmıştır. Geriye kalan ifadelerin faktör yükleri istatistiksel olarak anlamlıdır $(\mathrm{p}<0.001)$ Birleşik güvenirlik değerleri 0.966- 0.826 aralığında yer almaktadır. $\mathrm{Bu}$ sonuç yap1 güvenirliğini sağlandığına işaret etmektedir (Bagozzi \& Yi, 1988). Ölçeklerin alfa katsayıları $0.965-0.830$ değerleri arasında değişmektedir. Bu sonuç yapıların içsel tutarlılığına işaret etmektedir (Nunnally, 1978). Açıklanan ortalama varyans değerleri 0.855-0.548 aralığındadır. $\mathrm{Bu}$ sonuç yakınsak geçerliliğin sağlandığına işaret etmektedir (Fornell \& Larcker, 1981).

\section{BULGULAR}

\subsection{Korelasyonlar}

Ortalama, standart sapma ve korelasyon değerleri Tablo 2'de sunulmuştur. Bulgulara göre, YPIKKU iş gömülmüşlük $(r=.68, \mathrm{p}<0.01)$ işe adanma $(\mathrm{r}=$ $.56, \mathrm{p}<0.01)$ ve hizmet odaklı örgütsel vatandaşlık davranışı $(\mathrm{r}=.65, \mathrm{p}<0.01)$ ile olumlu ve anlamlı olarak ilişkilidir. İşe gömülmüşlük işe adanma $(\mathrm{r}=$ $.61, \mathrm{p}<0.01)$ ve hizmet odaklı örgütsel vatandaşlık davranışı $(\mathrm{r}=.44, \mathrm{p}<0.01)$ ile olumlu ve anlamlı olarak ilişkilidir. İşe adanma hizmet odaklı örgütsel vatandaşlık davranışı $(\mathrm{r}=.42, \mathrm{p}<0.01)$ ile olumlu ve anlamlı olarak ilişskilidir.

\subsection{Hipotez Testi}

YEM sonuçları $(\chi 2=3017.353 \mathrm{df}=1460, \mathrm{p}<0.001$ $\chi 2 / \mathrm{df}=2.067, \mathrm{RMSEA}=0.065, \mathrm{CFI}=0.94$, NFI $=$ 0.92), tüm tahminlerin anlamlı olduğunu göstermiştir. Sonuçlar, yüksek performanslı İK uygulamalarının işe adanmayı $(\beta=0.57 ; \mathrm{t}=4.789$; $\mathrm{p}<0.001)$ ve işe gömülmüşlüğü $(\beta=0.69 ; \mathrm{t}=$ 4.853; $\mathrm{p}<0.001$ ) olumlu anlamlı olarak etkilediğini göstermektedir. İşe adanma hizmet odaklı örgütsel vatandaşlık davranışını olumlu ve anlamlı olarak etkilemektedir $(\beta=0.45 ; \mathrm{t}=4.210 ; \mathrm{p}<0.001)$. İşe gömülmüşlük işe adanmayı olumlu ve anlamlı olarak etkilemektedir $(\beta=0.47 ; \mathrm{t}=3.689 ; \mathrm{p}<$ 0.001).

Tablo 2'de rapor edilen sonuçlara göre tüm doğrudan ilişkiler anlamlıdır. $\mathrm{Bu}$ nedenle aracılık testi için gerekli olan şartlar karşılanmıştır (Baron \& Kenny, 1986). $\chi 2$ farklılık testi kullanılarak tam aracılık modeli kısmi aracılık modeliyle kıyaslanmıştır. Sonuçlara göre tam aracılık modeli $(\chi 2=3017.353 \mathrm{df}=1460, \mathrm{p}<0.001 \chi 2 / \mathrm{df}=2.067$, $\mathrm{RMSEA}=0.065, \mathrm{CFI}=0.94, \mathrm{NFI}=0.92), \mathrm{k} 1 \mathrm{smi}$ aracilik modeline $(\chi 2=3026.653 \mathrm{df}=1461, \mathrm{p}<0$ $.001 \chi 2 / \mathrm{df}=2.072$, RMSEA $=0.066$, CFI $=0.92$, $\mathrm{NFI}=0.91)$ göre daha iyi uyum indislerine sahiptir $(\Delta \mathrm{X} 2=9.3 ; \mathrm{df}=1 ; \mathrm{p}<0.001) . \mathrm{Bu}$ bulgular işe adanmanın ve işe gömülmüşlügüü tam aracılık rolüne işaret etmektedir. Tam aracılık modeli sonuçları Şekil 2'de sunulmuş olup, model testinde iki aracı değişkene aynı anda yer verilmiştir. Yüksek performanslı insan kaynakları uygulamalarının hizmet odaklı örgütsel vatandaşlık davranışı üzerindeki dolaylı etkisi 0.58 'dir. Dolaylı etkilerin anlamlılığı değerlendirme için Sobel testi yerine daha güçlü bir yöntem olarak kabul edilen ön yükleme (alt örneklem değeri: 5.000) kullanılmıştır (Zhao, Lynch \& Chen, 2010). \% 95 güven aralığında dolaylı etkilerin altı ve üst değerleri sirasıyla 0.524-0.623'dir. $\mathrm{Bu}$ nedenle işe adanmanın ve işe gömülmüşlüğün aracılık etkisi anlamlidır. 
Tablo 1: Ölçüm modeli sonuçları

\begin{tabular}{|c|c|c|c|c|}
\hline Değişkenler & $\lambda$ & $a$ & BD $^{* *}$ & $\mathrm{AOV}^{* * * *}$ \\
\hline Yüksek performanslı insan kaynakları uygulamaları & & 0.913 & 0.933 & 0.703 \\
\hline Seçici işe alma & 0.88 & 0.942 & 0.926 & 0.758 \\
\hline A1 & 0.90 & & & \\
\hline $\mathrm{A} 2$ & 0.89 & & & \\
\hline A3 & 0.87 & & & \\
\hline A4 & 0.82 & & & \\
\hline Kapsamlı eğitim & 0.81 & 0.941 & 0.940 & 0.798 \\
\hline A5 & 0.86 & & & \\
\hline A6 & 0.90 & & & \\
\hline A7 & 0.94 & & & \\
\hline A8 & 0.87 & & & \\
\hline İstihdam güvenliği & 0.91 & 0.841 & 0.863 & 0.615 \\
\hline A9 & 0.62 & & & \\
\hline A10 & 0.76 & & & \\
\hline A11 & 0.85 & & & \\
\hline A12 & 0.88 & & & \\
\hline Performans Değerlendirme & 0.96 & 0.901 & 0.906 & 0.764 \\
\hline A13 & 0.85 & & & \\
\hline A14 & 0.92 & & & \\
\hline A15 & 0.85 & & & \\
\hline Ödüller & 0.69 & 0.959 & 0.948 & 0.786 \\
\hline A16 & 0.76 & & & \\
\hline A17 & 0.86 & & & \\
\hline A18 & 0.92 & & & \\
\hline A19 & 0.94 & & & \\
\hline $\mathrm{A} 20$ & 0.94 & & & \\
\hline Güçlendirme & 0.75 & 0.949 & 0.948 & 0.820 \\
\hline A21 & 0.81 & & & \\
\hline A22 & 0.85 & & & \\
\hline A23 & 0.97 & & & \\
\hline A 24 & 0.98 & & & \\
\hline İşe gömülmüşlük & & 0.890 & 0.919 & 0.619 \\
\hline B1 & 0,89 & & & \\
\hline B2 & 0,87 & & & \\
\hline B3 & 0,84 & & & \\
\hline B4 & 0,70 & & & \\
\hline B5 & 0,75 & & & \\
\hline B6 & 0.66 & & & \\
\hline B7 & 0.77 & & & \\
\hline
\end{tabular}


Tablo 1: Ölçüm modeli sonuçları (devamı)

\begin{tabular}{|c|c|c|c|c|}
\hline İşe adanma & & 0.858 & 0.874 & 0.699 \\
\hline Dinçlik & 0.79 & 0.930 & 0.946 & 0.855 \\
\hline $\mathrm{C} 1$ & 0.95 & & & \\
\hline $\mathrm{C} 2$ & 0.97 & & & \\
\hline $\mathrm{C} 3$ & 0.85 & & & \\
\hline Bağlanma & 0.93 & 0.928 & 0.943 & 0.847 \\
\hline $\mathrm{C} 4$ & 0.94 & & & \\
\hline C5 & 0.90 & & & \\
\hline C6 & 0.92 & & & \\
\hline Yoğunlaşma & 0.78 & 0.916 & 0.930 & 0.816 \\
\hline C7 & 0.90 & & & \\
\hline $\mathrm{C} 8$ & 0.92 & & & \\
\hline C9 & 0.89 & & & \\
\hline Hizmet odaklı ÖVD & & 0.920 & 0.850 & 0.654 \\
\hline Sadakat & 0.97 & 0.965 & 0.966 & 0.850 \\
\hline D1 & 0.91 & & & \\
\hline D2 & 0.95 & & & \\
\hline D3 & 0.92 & & & \\
\hline D4 & 0.91 & & & \\
\hline D5 & 0.92 & & & \\
\hline Hizmet sunum & 0.89 & 0.830 & 0.947 & 0.782 \\
\hline D6 & 0.87 & & & \\
\hline D7 & 0.89 & & & \\
\hline D8 & 0.92 & & & \\
\hline D9 & 0.85 & & & \\
\hline D10 & 0.89 & & & \\
\hline Katılım & 0.94 & 0.914 & 0.826 & 0.548 \\
\hline D11 & 0.91 & & & \\
\hline D12 & 0.73 & & & \\
\hline D13 & 0.66 & & & \\
\hline D14 & 0.63 & & & \\
\hline
\end{tabular}

Tablo 2: Ortalama, standart sapma ve korelasyon değerleri

\begin{tabular}{lcccc}
\hline Değişkenler & 1 & 2 & 3 & 4 \\
\hline 1. Yüksek performanslı insan kaynakları uygulamaları & 1 & & & \\
2.İșe gömülmüşlük & $.68^{*}$ & 1 & & \\
3.İșe adanma & $.56^{*}$ & $.61^{*}$ & 1 & \\
4. Hizmet odaklı örgütsel vatandaşlık davranışı & $.65^{*}$ & $.44^{*}$ & $.42^{*}$ & 1 \\
\hline Ortalama & 3.2 & 3.3 & 4.9 & 3.6 \\
Standart sapma & 0.7 & 0.9 & 1.3 & 0.8 \\
\hline
\end{tabular}
Not. ${ }^{*} \mathrm{p}<0.01$ 


\section{SONUC VE TARTIŞMA}

\subsection{Bulguların Özeti}

Yüksek performanslı insan kaynakları uygulamaları (YPİKU) işe adanmayı ve işe gömülmüşlüğü olumlu ve anlamlı olarak etkilemektedir. Buna göre YPİKU örgüt ve çalışanlar arasındaki sosyal değişim ilişkisini güçlendirerek işe adamayı ve işe gömülmüşlüğü artırmaktadır. Sosyal değişim teorisi perspektifinden, İK uygulamalarıyla kendilerine yapılan yatırımları gözlemleyen çalışanlar örgüte daha fazla işe adanma ve gömülmüşlük ile karşılık vermektedirler $\left(\mathbf{H}_{\mathbf{1}}, \mathbf{H}_{\mathbf{2}}\right)$. İşe gömülmüşlük ve işe adanma hizmet odaklı örgütsel vatandaşlık (ÖVD) davranışını olumlu ve anlamlı olarak etkilemektedir. Bu bulguya göre, işlerine kendilerini daha fazla adayan ve daha fazla işe gömülü olan çalışanlar iş rollerini aşmak suretiyle daha fazla hizmet odaklı ÖVD sergilemektedirler $\left(\mathbf{H}_{3}, \mathbf{H}_{\mathbf{4}}\right)$.

Araştırma bulguları, yüksek performanslı insan kaynakları uygulamalarının hizmet odaklı ÖVD üzerindeki etkisinde işe adanmanın ve işe gömülmüşlüğü tam aracılık rolüne işaret etmektedir. Buna göre birbiriyle uyumlu İK uygulamaları seti, işe adanmayı ve gömülmüşlüğü artırmak suretiyle hizmet odaklı ÖVD'yi artırmaktadır. Vatandaşlık davranışlarının resmi rol tanımlarının dışında olmaları nedeniyle ödül, firsat ve yararları içeren İK uygulamaları ile doğrudan teşvik edilemeyeceklerini (Organ, 1997), bunun yerine İK uygulamalarının bazı aracı değişkenleri tetiklemek suretiyle vatandaşlık davranışlarını etkileyebileceğine dair teorik arka plan (Podsakoff vd., 2000; Sun vd., 2007; Kehoe \&
Wright, 2013), doğrulanmıștır.

\subsection{Araştırmanın Teorik Katkısı}

Şimdiye kadar birkaç araştırma otel endüstrisinde hizmet odaklı ÖVD'nin öncüllerini incelemiştir (Gonzalez \& Garazo, 2006; Kim vd., 2010; Ma \& Qu, 2011; Tang \& Tang, 2012; Tang \& Tsaur, 2016). Bu araştırma yüksek performanslı insan kaynakları uygulamalarının hizmet odaklı ÖVD'nin bir öncülü olduğunu ortaya koyarak ÖVD hakkındaki teorik bilgi birikimine katk1 sağlamaktadır. Bununla beraber, bu araştırma ișe adanmanın ve iş gömülmüşlüğü hizmet odaklı ÖVD'nin öncülleri olduğunu ortaya koyarak alanyazını genişletmektedir.

Vatandaşlık davranışlarıyla ilgili yazın, rol ötesi davranışların ödül ve cezayla doğrudan motive edilemeyeceklerini vurgulamaktadır (Organ, 1997). İK uygulamaları bazı örgütsel yararların işgörenlere sunulmasına odaklanmaktadır. Bu nedenle, yüksek performanslı İK uygulamaları ve örgütsel vatandaşlık davranışı arasındaki ilişki bazı aracı değişkenlerle daha iyi açıklanabileceği iddia edilmektedir (Podsakoff vd., 2000; Kehoe \& Wright, 2013). Örneğin, Karatepe (2016) YPIKKU ile hizmet odaklı ÖVD arasındaki ilişkide iş tutumlarının (örneği: ișe adanma) aracılık rolünün araştırılması için çağrıda bulunmuştur. Bu araştırma birbiriyle uyumlu IKK uygulamalarının işe adanma ve işe gömülmüşlük aracılığıyla dolaylı olarak hizmet odaklı ÖVD'yi etkilediğini ortaya koyarak alanyazına katkı sağlamaktadır. Bir başka ifadeyle, bu araştırma yüksek performanslı insan kaynakları uygulamaları nasıl hizmet odaklı örgütsel

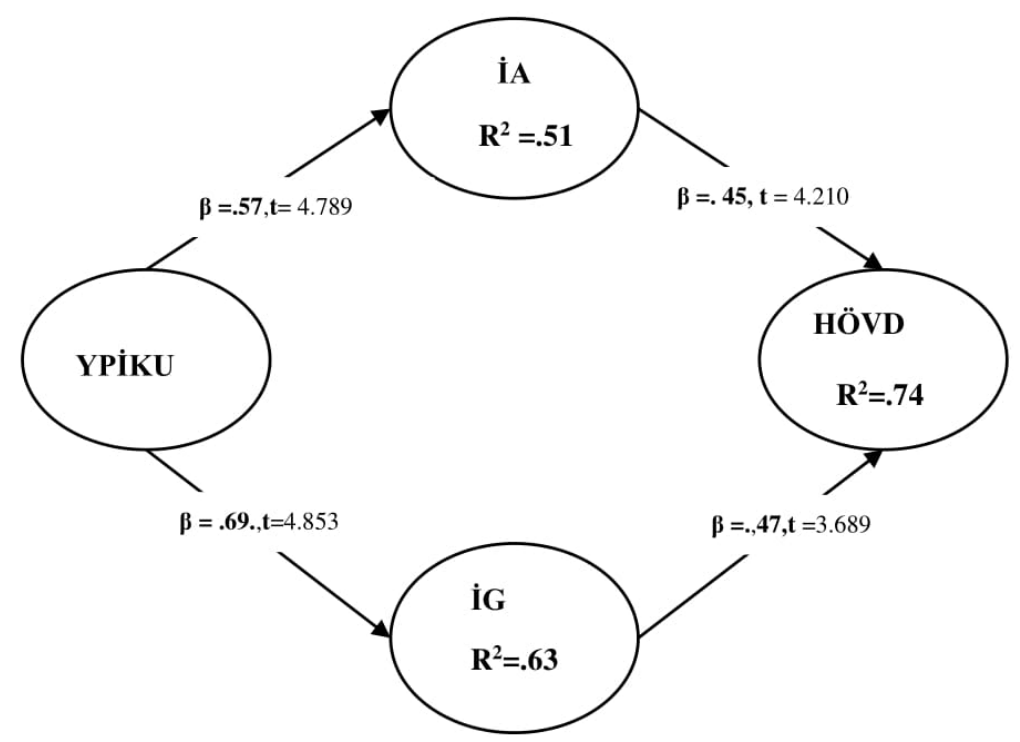

Not. YPIKUU=yüksek performanslı İK uygulamaları; İA= işe adanma; İG=I işe gömülmüşlük; HOVD=hizmet odaklı ÖVD

Şekil 2: Yapısal eşitlik modellemesi sonuçları 
vatandaşlık davranışını etkiler sorusuna, işe adanma ve işe gömülmüşlük kavramlarıyla cevap vererek alanyazını genişletmektedir.

\subsection{Araştırmanın Uygulamaya Katkısı}

$\mathrm{Bu}$ araştırma uygulamacılara birkaç katkı sağlamaktadır. Birincisi, bu araştırma yüksek performanslı insan kaynakları uygulamalarının örgütlere sunduğu yararlardan bir kesit sunmuştur. Bu bağlamda, örgütler İK uygulamaları paketlerini tasarlarken, birbirini tamamlayan ve içsel uyuma sahip İK uygulamalarını tercih etmelidirler (Gürlek, 2019a). Örneğin, seçici işe alma uygulaması, kapsamlı eğitim ve ödüller ile desteklenmelidir. Şöyle ki, seçici bir şekilde işe alınan ve daha sonra kapsamlı bir şekilde eğitilen bireyler, yüksek performansları karşılı̆̆ında ödüllendirilmezlerse, diğer uygulamalar amacına ulaşmayabilir. İkincisi, araştırma bulguları işe adanmanın ve işe gömülmüşlüğü hizmet odaklı ÖVD’yi artırdığını ortaya koymuştur. $\mathrm{Bu}$ nedenle örgütler işe adanmayı ve işe gömülmüşlüğü teşvik eden unsurlara daha fazla önem vermelidirler. Üçüncüsü, bu araştırma yüksek performanslı İK uygulamalarının doğrudan değil, fakat işe adanma ve işe gömülmüşlük aracılığıyla hizmet odaklı ÖVD'yi artırdığını ortaya koymuştur. $\mathrm{Bu}$ nedenle, uygulamacılar salt İK uygulamalarını değil, aynı zamanda işe adanmanın ve işe gömülmüşlügün önemini de anlamalıdırlar.

\subsection{Sınırlılıklar ve gelecek araştırmalara öneriler}

$\mathrm{Bu}$ araştırma kesitsel bir araştırma tasarımına sahiptir. $\mathrm{Bu}$ bakımdan, ele aldığı değişkenlerin zaman içerisinde gösterdiği değişim hakkında veri sunmamaktadır. Gelecek araştırmalar boylamsal bir araştırma dizaynı takip edebilirler. Bu araştırma otel çalışanlarına odaklamaktadır. Gelecek araştırmalar diğer hizmet sektörlerinde bulunan işgörenlere odaklanabilirler. $\mathrm{Bu}$ araştırma Ankara İlinde faaliyet gösteren dört ve beş yıldızlı otellerin işgörenleri üzerinde gerçekleştirilmiştir. Bu nedenle bulgular diğer bağlamlara genelleştirilemez. Gelecek araştırmalar farklı İllerde yer alan oteller üzerinde yapılabilir. $\mathrm{Bu}$ araştırma bağımlı ve bağımsız değişken arasındaki ilişki süreçlerini açıklamak için aracı süreçleri kullanırken, düzenleyici değişkenleri ele almamıştır. Gelecek araştırmalar ele alınan ilişki mekanizmasının doğasını daha iyi anlamak için insan kaynakları atıflarını ve İK uygulamalarını gerçekleştirilmesinde hat yöneticilerinin rolünü düzenleyici bir değişken olarak kullanabilirler. İnsan kaynakları atıfları göreceli olarak yeni araştırma alanıdır ve İK uygulamalarının uygulanış nedenleri hakkında yönetim niyetine yönelik çalışanların yaptığı yorumlara odaklanmaktadır
(Nishii, Lepak \& Schneider, 2008). Örneğin, çalışanlar İK uygulamalarının kendileri sömürmek veya daha fazla yararlanmak için yapıldığını düşünürlerse, örgüte olumlu tepkiler vermeyebilirler (Gürlek, 2019a). Diğer yandan, İK uygulamalarının olumlu işgören davranışlarına dönüşmesi hat yöneticilerine bağlidır. $\mathrm{Bu}$ nedenle, hat yöneticilerinin İKY uygulamalarının gerçekleştirilmesindeki etkinliği (Bos-Nehles, Van Riemsdijk \& Kees Looise, 2013) bir düzenleyici değişken olarak ele alınabilir. Bu araştırma yüksek performanslı insan kaynakları uygulamalarının hizmet odaklı örgütsel vatandaşlık davranış1 üzerindeki etkisinde sadece işe adanma ve işe gömülmüşlük değişkenlerinin aracılık rolünü incelemiştir. Gelecek araştırmalar, iyi oluş, hizmet yatkınlığı, adalet iklimi gibi değişkenleri aracı değişkenler olarak kullanabilirler. Mevcut araştırma kapsamında, aracı değişkenler aynı anda analize sokulmuş ve toplam dolaylı etki tespit edilmiştir. Gelecek araştırmalar, Hayes'in (2018) PROCESS macro programını veya PLS yapısal eşitlik programı kullanarak spesifik dolaylı etkileri tespit edebilirler ve böylece dolaylı etkileri karşılaştırabilirler.

\section{SONUÇ}

$\mathrm{Bu}$ araştırma, yüksek performanslı insan kaynakları uygulamalarının hizmet odaklı örgütsel vatandaşlık davranışını nasıl etkilediğini ortaya çıkarmayı amaçlamıştır. $\mathrm{Bu}$ amaca yönelik olarak işe adanmanın ve işe gömülmüşlügü aracılık rolü incelenmiştir. Yukarıda belirtilen ilişkileri test etmek için kullanılan veri dört ve beş yıldızlı otel işletmelerinin işgörenlerinden elde edilmiş̧ir. Araştırma hipotezlerinin test edilmesinde, yapısal eşitlik modellemesinden yararlanılmıştır. Bulgular, yüksek performanslı insan kaynakları uygulamalarının işe adanma, işe gömülmüşlük ve hizmet odaklı ÖVD üzerinde olumlu ve anlamlı bir etkiye sahip olduğunu göstermektedir. Yanı sıra, bulgular işe adanmanın ve işe gömülmüşlüğün hizmet odaklı ÖVD üzerinde olumlu ve anlamlı bir etkiye sahip olduğunu ortaya çıkarmıştır. Bununla beraber, bağımsız ve bağımlı değişken arasında işe adanmanın ve işe gömüşlüğün tam aracılık rolleri doğrulanmıştır. Sonuç olarak, bu araştırma yüksek performanslı insan kaynakları ve hizmet odaklı ÖVD arasındaki ilişki mekanizmasının anlaşılmasına katkı sağlamaktadır.

\section{ETIKK BEYANATI}

Destek Bilgisi: $\mathrm{Bu}$ çalışma herhangi bir organizasyondan destek almamıştır. 
Çıkar Çatışması: Çıkar çatışması yoktur.

Etik Onayı: Gerçekleştirilen tüm prosedürler, kurumsal ve / veya ulusal araştırma komitesinin etik standartlarına ve 1964 Helsinki deklarasyonuna ve daha sonraki değişikliklerine veya karşılaştırılabilir etik standartlara uygundur.

Bilgilendirilmiş Onam Formu: Çalışmaya katılan tüm bireysel katılımcılar kendi rıza ve istekleriyle araştırmaya dahil olmuştur.

\section{KAYNAKÇA}

Afsar, B., Shahjehan, A. \& Shah, S. I. (2018). Frontline employees' high-performance work practices, trust in supervisor, job-embeddedness and turnover intentions in hospitality industry. International Journal of Contemporary Hospitality Management, 30(3), 14361452.

Alfes, K., Shantz, A. D., Truss, C. \& Soane, E. C. (2013). The link between perceived human resource management practices, engagement and employee behaviour: a moderated mediation model. The international journal of human resource management, 24(2), 330-351.

Anderson, J. C. \& Gerbing, D. W. (1988). Structural equation modeling in practice: $\mathrm{A}$ review and recommended two-step approach. Psychological bulletin, 103(3), 411-423.

Babcock-Roberson, M. E. \& Strickland, O. J. (2010). The relationship between charismatic leadership, work engagement, and organizational citizenship behaviors. The Journal of psychology, 144(3), 313326.

Bagozzi, R. P. \& Yi, Y. (1988). On the evaluation of structural equation models. Journal of the academy of marketing science, 16(1), 74-94.

Bamberger, P. \& Meshoulam, I. (2000). Human resource management strategy. London: Published Sage.

Baron, R. M. \& Kenny, D. A. (1986). The moderatormediator variable distinction in social psychological research: Conceptual, strategic, and statistical considerations. Journal of personality and social psychology, 51(6), 1173-1182.

Bavik, A. (2019). Corporate social responsibility and service-oriented citizenship behavior: A test of dual explanatory paths. International Journal of Hospitality Management, 80, 173-182.

Becker, B. E. \& Huselid, M. A. (1998). High performance work systems and firm performance: A synthesis of research and managerial applications. Research in Personnel and Human Resources Management, 16, 53-101.

Bergiel, E. B., Nguyen, V. Q., Clenney, B. F. \& Stephen Taylor, G. (2009). Human resource practices, job embeddedness and intention to quit. Management Research News, 32(3), 205-219.

Bettencourt, L. A. \& Brown, S. W. (1997). Contact employees: Relationships among workplace fairness, job satisfaction and prosocial service behaviors. Journal of retailing, 73(1), 39-61. 
Bettencourt, L. A., Gwinner, K. P. \& Meuter, M. L. (2001). A comparison of attitude, personality, and knowledge predictors of service-oriented organizational citizenship behaviors. Journal of applied psychology, 86(1), 29-41.

Blau, P. (1964). Exchange and power in social life. New York: Wiley

Borman, W.C. \& Motowidlo, S. J. (1993). Expanding the criterion domain to include elements of contextual performance. In N. Schmitt \& W. C. Borman Ws.), Personnel selection in organizations. San Francisco: Jossey-Bass.

Boshoff, C. \& Allen, J. (2000). The influence of selected antecedents on frontline staff's perceptions of service recovery performance. International Journal of Service Industry Management, 11(1), 63-90.

Bos-Nehles, A. C., Van Riemsdijk, M. J. \& Kees Looise, J. (2013). Employee perceptions of line management performance: applying the AMO theory to explain the effectiveness of line managers' HRM implementation. Human resource management, 52(6), 861-877.

Boxall, P. \& Macky, K. (2009). Research and theory on high-performance work systems: progressing the high-involvement stream. Human resource management journal, 19(1), 3-23.

Brislin, R. W. (1970). Back-translation for cross-cultural research. Journal of cross-cultural psychology, 1(3), 185-216.

Cable, D. M. \& DeRue, D. S. (2002). The convergent and discriminant validity of subjective fit perceptions. Journal of applied psychology, 87(5), 875-884.

. Chiang, Y. H., Shih, H. A. \& Hsu, C. C. (2014). High commitment work system, transactive memory system, and new product performance. Journal of Business Research, 67(4), 631-640.

Chiu, S. F. \& Tsai, M. C. (2006). Relationships among burnout, job involvement, and organizational citizenship behavior. The Journal of Psychology, 140(6), 517-530.

Choo, L. S. (2016). A study of the role of work engagement in promoting service-oriented organizational citizenship behavior in the Malaysian hotel sector. Global Business and Organizational Excellence, 35(4), 28-43.

Cooke, F. L., Cooper, B., Bartram, T., Wang, J. \& Mei, H. (2019). Mapping the relationships between highperformance work systems, employee resilience and engagement: a study of the banking industry in China. The International Journal of Human Resource Management, 30(8), 1239-1260.
Crossley, C. D., Bennett, R. J., Jex, S. M. \& Burnfield, J. L. (2007). Development of a global measure of job embeddedness and integration into a traditional model of voluntary turnover. Journal of Applied Psychology, 92(4), 1031.

Delaney, J. T. \& Huselid, M. A. (1996). The impact of human resource management practices on perceptions of organizational performance. Academy of Management journal, 39(4), 949-969.

Delery, J. E. \& Doty, D. H. (1996). Modes of theorizing in strategic human resource management: Tests of universalistic, contingency, and configurational performance predictions. Academy of management Journal, 39(4), 802-835.

Demerouti, E. \& Bakker, A. B. (2011). The job demandsresources model: Challenges for future research. $S A$ Journal of Industrial Psychology, 37(2), 01-09.

Domínguez-Falcón, C., Martín-Santana, J. D. \& De SaáPérez, P. (2016). Human resources management and performance in the hotel industry: The role of the commitment and satisfaction of managers versus supervisors. International Journal of Contemporary Hospitality Management, 28(3), 490-515.

Fornell, C. \& Larcker, D. F. (1981). Evaluating structural equation models with unobservable variables and measurement error. Journal of marketing research, 18(1), 39-50.

Garba, O. A., Babalola, M. T. \& Guo, L. (2018). A social exchange perspective on why and when ethical leadership foster customer-oriented citizenship behavior. International Journal of Hospitality Management, 70, 1-8.

Ghosh, D. \& Gurunathan, L. (2015). Do commitment based human resource practices influence job embeddedness and intention to quit?. IIMB Management Review, 27(4), 240-251.

Gupta, N. \& Sharma, V. (2018). Relationship between leader member exchange (LMX), high-involvement HRP and employee resilience on extra-role performance: Mediating role of employee engagement. Journal of Indian Business Research, 10(2), 126-150.

Guthrie, J. P. (2001). High-involvement work practices, turnover, and productivity: Evidence from New Zealand. Academy of management Journal,44(1), 180-190.

Gürlek, M. (2018). Kurumsal sosyal sorumluluğun işe adanma üzerindeki etkisinde algllanan dışsal prestijin ve örgütsel özdeşleşmenin aracilı rolü: otel işletmelerinde bir araştırma. Gazi Üniversitesi Sosyal Bilimler Enstitüsü, Turizm İşletmeciliği Anabilim Dalı, Yayımlanmamış Doktora Tezi. 
Gürlek, M. (2019a). Hizmet odakl yüksek performansl insan kaynakları uygulamalarının işgören hizmet performanst üzerindeki etkisinde aracı ve düzenleyici değişkenlerin rolü. Gazi Üniversitesi Sosyal Bilimler Enstitüsü, Yönetim Organizasyon Bilim Dalı, Yayımlanmamış Doktora Tezi.

Gürlek (2019b). The effects of workplace incivility on turnover intention: the mediating role of job embeddedness. Global Conference on Business and Economics. September 30 - October 3. İstanbul

Gürlek, M. \& Tuna, M. (2019). Corporate social responsibility and work engagement: Evidence from the hotel industry. Tourism Management Perspectives, 31, 195-208.

Hayes, A. F. (2018). Introduction to mediation, moderation, and conditional process analysis: $A$ regression-based approach. (Second Edition), Guilford Publications.

Holtom, B. C., Burton, J. P. \& Crossley, C. D. (2012). How negative affectivity moderates the relationship between shocks, embeddedness and worker behaviors. Journal of Vocational Behavior, 80(2), 434-443.

Huang, Y., Ma, Z. \& Meng, Y. (2018). High-performance work systems and employee engagement: empirical evidence from China. Asia Pacific Journal of Human Resources, 56(3), 341-359.

James, L. R., Mulaik, S. A. \& Brett, J. M. (2006). A tale of two methods. Organizational research methods, 9(2), 233-244.

Jeong, I. \& Shin, S. J. (2019). High-performance work practices and organizational creativity during organizational change: A collective learning perspective. Journal of Management, 45(3), 909-925.

Kang, J. \& Jang, J. (2019). Fostering service-oriented organizational citizenship behavior through reducing role stressors. International Journal of Contemporary Hospitality Management. https://doi.org/10.1108/IJCHM-12-2018-1018

Kang, H. J. A., Kim, W. G., Choi, H. M. \& Li, Y. (2020). How to fuel employees' prosocial behavior in the hotel service encounter. International Journal of Hospitality Management, 84, 102333. https://doi.org/10.1016/j.ijhm.2019.102333.

Kanten, P., Kanten, S. \& Gürlek, M. (2015). The effects of organizational structures and learning organization on job embeddedness and individual adaptive performance. Procedia Economics and Finance, 23, 1358-1366.

Karadas, G. \& Karatepe, O. M. (2019). Unraveling the black box: The linkage between high-performance work systems and employee outcomes. Employee Relations, 41(1), 67-83.

Karatepe, O. M. (2012). Job resources, work engagement, and hotel employee outcomes: a time-lagged analysis. Economic research-Ekonomska istraživanja, 25(3), 644-665.

Karatepe, O. M. (2013a). High-performance work practices and hotel employee performance: The mediation of work engagement. International Journal of Hospitality Management, 32, 132-140.

Karatepe, O. M. (2013b). High-performance work practices, work social support and their effects on job embeddedness and turnover intentions. International Journal of Contemporary Hospitality Management, 25(6), 903-921.

Karatepe, O. M. (2016). Does job embeddedness mediate the effects of coworker and family support on creative performance? An empirical study in the hotel industry. Journal of Human Resources in Hospitality \& Tourism, 15(2), 119-132.

Karatepe, O. M. \& Karadas, G. (2012). The effect of management commitment to service quality on job embeddedness and performance outcomes. Journal of Business Economics and Management, 13(4), 614636.

Karatepe, O. M. \& Vatankhah, S. (2014). The effects of high-performance work practices and job embeddedness on flight attendants' performance outcomes. Journal of Air Transport Management, 37, 27-35.

Kehoe, R. R. \& Wright, P. M. (2013). The impact of high-performance human resource practices on employees' attitudes and behaviors. Journal of management, 39(2), 366-391.

Kim, J. \& Gatling, A. (2019). Impact of employees' job, organizational and technology fit on engagement and organizational citizenship behavior. Journal of Hospitality and Tourism Technology. https://doi.org/10.1108/JHTT-04-2018-0029

Kim, S., O’Neill, J. W. \& Cho, H. M. (2010). When does an employee not help coworkers? The effect of leader-member exchange on employee envy and organizational citizenship behavior. International Journal of Hospitality Management, 29(3), 530-537.

Kline, R. B. (2011). Principles and practice of structural equation modeling (3rd ed.). New York, NY: The Guilford Press.

Kusluvan, S., Kusluvan, Z., Ilhan, I. \& Buyruk, L. (2010). The human dimension: A review of human resources management issues in the tourism and hospitality industry. Cornell Hospitality Quarterly, 51(2), 171214. 
Kültür ve Turizm Bakanlığı (2019). Turizm işletmesi belgeli tesisler listesi. https:/yigm.ktb.gov.tr/TR9579/turizm-tesisleri.html adresinden Mart 2019'da alınmıştır.

Lee, J. \& Ok, C. M. (2016). Hotel employee work engagement and its consequences. Journal of Hospitality Marketing \& Management, 25(2), 133166.

Lee, T. W., Mitchell, T. R., Sablynski, C. J., Burton, J. P. \& Holtom, B. C. (2004). The effects of job embeddedness on organizational citizenship, job performance, volitional absences, and voluntary turnover. Academy of management journal,47(5), 711-722.

Lee, Y. K., Choi, J., Moon, B. Y. \& Babin, B. J. (2014). Codes of ethics, corporate philanthropy, and employee responses. International Journal of Hospitality Management, 39, 97-106.

Lin, Y. T. \& Liu, N. C. (2016). High performance work systems and organizational service performance: The roles of different organizational climates. International Journal of Hospitality Management, 55, 118-128.

Liu, N. C. \& Lin, Y. T. (2019). High-performance work systems, management team flexibility, employee flexibility and service-oriented organizational citizenship behaviors. The International Journal of Human Resource Management, 1-38. https://doi.org/10.1080/09585192.2019.1651374

Llorens, S., Bakker, A. B., Schaufeli, W. \& Salanova, M. (2006). Testing the robustness of the job demandsresources model. International Journal of Stress Management, 13(3), 378-391.

Luu, T. T. (2019). Service-oriented high-performance work systems and service-oriented behaviours in public organizations: the mediating role of work engagement. Public Management Review, 21(6), 789816

Ma, E. \& Qu, H. (2011). Social exchanges as motivators of hotel employees' organizational citizenship behavior: The proposition and application of a new three-dimensional framework. International journal of hospitality management, 30(3), 680-688.

Macky, K. \& Boxall, P. (2008). High-involvement work processes, work intensification and employee wellbeing: A study of New Zealand worker experiences. Asia Pacific Journal of Human Resources, 46(1), 38-55.

Matta, F. K., Scott, B. A., Koopman, J. \& Conlon, D. E. (2015). Does seeing "eye to eye" affect work engagement and organizational citizenship behavior? A role theory perspective on LMX agreement. Academy of Management Journal, 58(6), 1686-1708.

Mihail, D. M. \& Kloutsiniotis, P. V. (2016). The effects of high-performance work systems on hospital employees' work-related well-being: Evidence from Greece. European Management Journal, 34(4), 424438 .

Mitchell, R., Obeidat, S. \& Bray, M. (2013). The effect of strategic human resource management on organizational performance: the mediating role of high-performance human resource practices. Human Resource Management, 52(6), 899-921.

Mitchell, T. R., Holtom, B. C., Lee, T. W., Sablynski, C. J. \& Erez, M. (2001). Why people stay: Using job embeddedness to predict voluntary turnover. Academy of management journal, 44(6), 1102-1121.

Murphy, K. S. \& Williams, J. A. (2010). Human resource management high-performance work practices and contextual setting: Does industry matter? A comparison of the US restaurant sector to the manufacturing industry. Journal of Foodservice Business Research, 13(4), 283-303.

Nadeem, K., Riaz, A. \& Danish, R. Q. (2019). Influence of high-performance work system on employee service performance and OCB: the mediating role of resilience. Journal of Global Entrepreneurship Research, 9(1), 13.

Nasurdin, A. M., Ahmad, N. H. \& Tan, C. L. (2015). Cultivating service-oriented citizenship behavior among hotel employees: the instrumental roles of training and compensation. Service Business, 9(2), 343-360.

Ng, T. W. \& Feldman, D. C. (2009). Occupational embeddedness and job performance. Journal of Organizational Behavior: The International Journal of Industrial, Occupational and Organizational Psychology and Behavior, 30(7), 863-891.

Nishii, L. H., Lepak, D. P. \& Schneider, B. (2008). Employee attributions of the "why" of HR practices: Their effects on employee attitudes and behaviors, and customer satisfaction. Personnel psychology, 61(3), 503-545.

Nunnally, J. C. (1978). Psychometric Theory, McGrawHill, New York.

Organ, D. W. (1990). The motivational basis of organizational citizenship behavior. In B. M. Staw \& L. L. Cummings (Eds.), Research in organizational behavior, vol. 12: 43-72. Greenwich,

Organ, D. W. (1997). Organizational citizenship behavior: It's construct clean-up time. Human performance, 10(2), 85-97. 
Organ, D. W., Podsakoff, P. M. \& MacKenzie, S. B. (2006). Organizational citizenship behavior: Its nature, antecedents, and consequences. USA: Sage Publications.

Paré, G. \& Tremblay, M. (2007). The influence of highinvolvement human resources practices, procedural justice, organizational commitment, and citizenship behaviors on information technology professionals' turnover intentions. Group \& Organization Management, 32(3), 326-357.

Podsakoff, P. M., MacKenzie, S. B., Paine, J. B. \& Bachrach, D. G. (2000). Organizational citizenship behaviors: A critical review of the theoretical and empirical literature and suggestions for future research. Journal of management, 26(3), 513-563.

Qiu, S., Alizadeh, A., Dooley, L. M. \& Zhang, R. (2019). The effects of authentic leadership on trust in leaders, organizational citizenship behavior, and service quality in the Chinese hospitality industry. Journal of Hospitality and Tourism Management, 40, 77-87.

Saks, A. M. (2006). Antecedents and consequences of employee engagement. Journal of managerial psychology, 21(7), 600-619.

Salanova, M. \& Schaufeli, W. B. (2008). A cross-national study of work engagement as a mediator between job resources and proactive behaviour. The International Journal of Human Resource Management, 19(1), 116-131.

Sardeshmukh, S. R. \& Vandenberg, R. J. (2017). Integrating moderation and mediation: A structural equation modeling approach. Organizational Research Methods, 20(4), 721-745.

Schaufeli, W. B. \& Bakker, A. B. (2004). Job demands, job resources, and their relationship with burnout and engagement: A multi-sample study. Journal of Organizational Behavior: The International Journal of Industrial, Occupational and Organizational Psychology and Behavior, 25(3), 293-315.

Schaufeli, W. B., Bakker, A. B. \& Salanova, M. (2006). The measurement of work engagement with a short questionnaire: A cross-national study. Educational and psychological measurement, 66(4), 701-716.

Schaufeli, W. B., Salanova, M., González-Romá, V. \& Bakker, A. B. (2002). The measurement of engagement and burnout: A two sample confirmatory factor analytic approach. Journal of Happiness studies, 3(1), 71-92.

Schermelleh-Engel, K., Moosbrugger, H. \& Müller, H. (2003). Evaluating the fit of structural equation models: Tests of significance and descriptive goodness-of-fit measures. Methods of psychological research online, 8(2), 23-74.
Sekiguchi, T., Burton, J. P. \& Sablynski, C. J. (2008). The role of job embeddedness on employee performance: the interactive effects with leadermember exchange and organization-based self-esteem. Personnel Psychology, 61(4), 761-792.

Shaw, J. D., Dineen, B. R., Fang, R. \& Vellella, R. F. (2009). Employee-organization exchange relationships, HRM practices, and quit rates of good and poor performers. Academy of Management Journal, 52(5), 1016-1033.

Snape, E. \& Redman, T. (2010). HRM practices, organizational citizenship behaviour, and performance: A multi-level analysis. Journal of management studies, 47(7), 1219-1247.

Sun, L. Y., Aryee, S. \& Law, K. S. (2007). Highperformance human resource practices, citizenship behavior, and organizational performance: A relational perspective. Academy of management Journal, 50(3), 558-577.

Sweetman, D. \& Luthans, F. (2010). The power of positive psychology: Psychological capital and work engagement. Work engagement: A handbook of essential theory and research, 54-68.

Tang, T. W. \& Tang, Y. Y. (2012). Promoting serviceoriented organizational citizenship behaviors in hotels: The role of high-performance human resource practices and organizational social climates. International Journal of Hospitality Management, 31(3), 885-895.

Tang, Y. Y. \& Tsaur, S. H. (2016). Supervisory support climate and service-oriented organizational citizenship behavior in hospitality: The role of positive group affective tone. International Journal of Contemporary Hospitality Management, 28(10), 2331-2349.

Theriou, G. N. \& Chatzoglou, P. D. (2009). Exploring the best HRM practices-performance relationship: An empirical approach. Journal of Workplace Learning, 21(8), 614-646.

Tian, A. W., Cordery, J. \& Gamble, J. (2016). Staying and performing: How human resource management practices increase job embeddedness and performance. Personnel Review, 45(5), 947-968.

Tsaur, S. H. \& Lin, Y. C. (2004). Promoting service quality in tourist hotels: the role of HRM practices and service behavior. Tourism management, 25(4), 471-481.

UNWTO. (2018). UNWTO tourism highlights-2018 edition. Madrid: World Tourism Organization.

Van Dyne, L., Graham, J. W. \& Dienesch, R. M. (1994). Organizational citizenship behavior: Construct 
redefinition, measurement, and validation. Academy of management Journal, 37(4), 765-802.

Varela González, J. \& García Garazo, T. (2006). Structural relationships between organizational service orientation, contact employee job satisfaction and citizenship behavior. International Journal of Service Industry Management, 17(1), 23-50.

Wheeler, A. R., Harris, K. J. \& Harvey, P. (2010). Moderating and mediating the HRM effectivenessintent to turnover relationship: The roles of supervisors and job embeddedness. Journal of Managerial Issues, 182-196.

Xanthopoulou, D., Bakker, A. B., Dollard, M. F., Demerouti, E., Schaufeli, W. B., Taris, T. W. \& Schreurs, P. J. (2007). When do job demands particularly predict burnout? The moderating role of job resources. Journal of managerial psychology, 22(8), 766-786.

Xiao, Z. \& Björkman, I. (2006). High commitment work systems in Chinese organizations: A preliminary measure. Management and Organization Review, 2(3), 403-422.

Yung Chou, S. \& Lopez-Rodriguez, E. (2013). An empirical examination of service-oriented organizational citizenship behavior: The roles of justice perceptions and manifest needs. Managing Service Quality, 23(6), 474-494.

Zhang, Z., Wan, D. \& Jia, M. (2008). Do highperformance human resource practices help corporate entrepreneurship? The mediating role of organizational citizenship behavior. The Journal of High Technology Management Research, 19(2), 128138.

Zhao, X., Lynch Jr, J. G. \& Chen, Q. (2010). Reconsidering Baron and Kenny: Myths and truths about mediation analysis. Journal of consumer research, 37(2), 197-206.

Zhong, L., Wayne, S. J. \& Liden, R. C. (2016). Job engagement, perceived organizational support, high-performance human resource practices, and cultural value orientations: A cross-level investigation. Journal of Organizational Behavior, 37(6), 823-844. 